\title{
New records of Gerromorpha (Insecta: Hemiptera: Heteroptera) from the Neotropical Region
}

\section{CARLA FERNANDA BURGUEZ FLORIANO ${ }^{A, ~ B}$, FELIPE FERRAZ FIGUEIREDO MOREIRA ${ }^{\mathrm{C}}$, PITÁGORAS DA CONCEIÇÃO BISPO ${ }^{A}$}

\author{
${ }^{a}$ Department of Biological Sciences, Universidade Estadual Paulista, Assis, SP, Brazil. \\ ${ }^{\mathrm{b}}$ Department of Biology, Universidade de São Paulo, Ribeirão Preto, SP, Brazil. carlla.floriano@gmail.com. \\ ${ }^{c}$ Laboratório de Biodiversidade Entomológica, Instituto Oswaldo Cruz, Fundação Oswaldo Cruz, Rio de Janeiro, RJ, \\ Brazil.
}

\begin{abstract}
Gerromorpha or semiaquatic bugs have the ability to walk on the surface of the water and occupy a wide variety of habitats. They are relatively well studied in the Neotropical Region, but some species are known only from the type localities or have many gaps in their documented distributions. In this study we examined specimens housed in the National Museum of Natural History, Smithsonian Institution, and report new records for 17 species: Mesovelia bila, Hydrometra argentina, H. caraiba, H. comata, Limnobatodes paradoxus, Euvelia lata, E. mazzucconiae, Husseyella turmalis, Oiovelia cunucunumana, Paravelia conata, Platyvelia brachialis, Steinovelia virgata, Halobatopsis platensis, H. spiniventris, Ovatametra obesa, Limnogonus aduncus aduncus, and L. recurvus.
\end{abstract}

Key words: distribution, America, Hydrometridae, Gerridae, Mesoveliidae, Veliidae.

\section{INTRODUCTION}

Gerromorpha or semiaquatic bugs have the ability to walk on the surface of the water (Andersen 1982a; Schuh and Slater 1995) and occupy a wide variety of habitats, usually in streams, rivers, and lakes (Andersen 1982a). Some species occupy particular habitats such as the open ocean, rocky coastal shores, intertidal marine zones, phytotelmata, crevices and holes in rocks, hygropetric habitats, caves, wet moss near aquatic environments, or can be found far from water bodies (Andersen 1982a; Andersen 1982b; Spence and Andersen 1994; Schuh and Slater 1995; Andersen and Polhemus 2003; Damgaard et al. 2012).

The infraorder Gerromorpha comprises more than 2100 species of eight families, out of which over 500 species of seven families have been recorded from the Neotropical Region: Gerridae (141 spp.), Hebridae (31 spp.), Hermatobatidae (1 sp.), Hydrometridae (37 spp.), Macroveliidae (1 sp.), Mesoveliidae (15 spp.) and Veliidae (290 spp.) (Polhemus and Polhemus 2008; Moreira 2015). In the last few decades, Neotropical Gerromorpha have been the target of many faunistic and taxonomic studies, so the group has become relatively well known (Polhemus and Polhemus 2007; Moreira 2015).

However, there are many undescribed species from the region, mainly in the family Veliidae (Microveliinae) (Polhemus and Polhemus 2007); furthermore, the geographical distribution of described species usually contains many gaps. The inadequate knowledge of the real distribution of species is known as Wallacean shortfall (Whittaker et al. 2005) and reducing this deficit is crucial to a better understanding of biodiversity. Thus, we studied specimens housed in the National Museum of Natural History, Smithsonian Institution, in order to contribute to reducing the Wallacean shortfall for semiaquatic bugs of the Neotropical Region. Here, we report new geographic records for 17 species of 
Gerromorpha from this region.

\section{METHODS}

This study is based on the examination of dry specimens deposited in the National Museum of Natural History, Smithsonian Institution, Washington D.C., USA (NMNH). Label data are given inside quotation marks, with a reversed slash $(\backslash)$ separating lines on the labels and a semicolon separating labels of a specimen. We used the software Qgis 2.6.1 to make the maps.

The topic "known distribution" is presented as follows: the first locality is the country and inside parentheses is the state, province or department. A question mark inside parentheses, (?), indicates that specific localities are not known. On the topic "new records", the first locality is the new record and the country is inside parentheses. Unless otherwise noted, the previously known distributions are based on Moreira et al. $(2011,2016)$ and Moreira (2015, 2016).

\section{MESOVELIIDAE DOUGLAS AND SCOTT Mesoveliinae Douglas and Scott}

\section{Mesovelia bila Jaczewski}

Known distribution - Brazil (São Paulo and Paraná) and Argentina (Misiones, Corrientes, Entre Ríos, and Buenos Aires).

Material examined - $1 \hat{\sigma}(\mathrm{NMNH})$ : 'Nova Teutonia\ St. Catarina\ Bras. XII-1956 Fritz Plaumann'.

Notes - This is the first record of M. bila from Santa Catarina State (Brazil) (Fig. 1).

\section{HYDROMETRIDAE BILLBERG}

\section{Hydrometrinae Billberg}

\section{Hydrometra argentina Berg}

Known distribution - Panama (?), Trinidad and Tobago (San Juan-Laventille, Tunapuna-Piarco, and Río Claro-Mayaro), Colombia (Antioquia, Cundinamarca, and Meta), Venezuela (?), Suriname (Paramaribo and Para), Brazil (Amapá, Amazonas,
Pará, Paraíba, Bahia, Mato Grosso, Mato Grosso do Sul, Minas Gerais, Rio de Janeiro, São Paulo, Paraná, Santa Catarina, and Rio Grande do Sul), Ecuador (Manabi), Peru (Loreto and Lima), Bolivia (?), Chile (O’Higgins), Paraguay (Guairá), Argentina (Formosa, Chaco, Misiones, Corrientes, Rioja, Córdoba, Entre Ríos, Buenos Aires, Río Negro, and Chubut), and Uruguay (Rivera and Montevideo).

Material examined $-5 \hat{\jmath}, 3 q$ (NMNH): 'Chile: Pencahue $\backslash$ Talca Prov. $\ 20$ km, W. Talca XII-27 . 1972'.

Notes - This is the first record of H. argentina from Maule Region (Chile) (Fig. 2).

\section{Hydrometra caraiba Guérin-Méneville}

Known distribution - Mexico (?), Guatemala (Izabal and Zacapa), Honduras (?), Nicaragua (?), El Salvador (?), Costa Rica (Guanacaste, Alajuela, and Puntarenas), Panama (Chiriquí and Panama), Cuba (Pinar del Río, Cienfuegos, Holguín, and Guantánamo), Jamaica (?), Haiti (?), Puerto Rico (?), Guadeloupe (Pointe-à-Pitre), Martinique (Le Marin), Trinidad and Tobago (Siparia), Colombia (Magdalena, Atlántico, Cesar, Antioquia, Valle del Cauca, Quindío, and Nariño), Venezuela (?), Brazil (Amazonas), Ecuador (Esmeraldas and Guayas), and Peru (Madre de Dios).

Material examined - 1ڤ, 3 ㅇ $(\mathrm{NMNH})$ : 'Venezuela: Guanare, estado\ Portuguesa\ IX-10 to 13-1957' 'Borys Malkin $\backslash$ Collector'. 20ิ, 1 우 (NMNH): 'Ecuador: Los $\backslash$ Rios Babahoyo $\backslash(20 \mathrm{Km}$ N.)\} 2 2 \text { June } 1 9 7 5 \text { ' 'Collected by } \backslash \text { A. Langley, J J. } Cohen, $\backslash$ P. Monning’.

Notes. This is the first record of H. caraiba from Los Ríos Province (Ecuador) and the confirmation of its occurrence in Venezuela (Fig. 3). It was previously recorded from the latter without details by Drake (1954).

\section{Hydrometra comata Torre-Bueno}

Known distribution - Trinidad and Tobago (Siparia), Colombia (Valle del Cauca and Quindío), Suriname (Brokopondo), and Brazil (Pará and Mato Grosso).

Material examined - 1ठ, 2 + (NMNH): '24 kil. E. Formoso, \GO., Brazil \June 5, 1956 $\backslash$ F.S. Truxal'. 
3 (NMNH): 'Venezuela, Amazonas $\backslash$ stream at Puente Pulda $\backslash 16$ Km. N. of Tobogan jct. $\backslash 26$ January 1989 CL $2387 \backslash$ J. T. Polhemus'.

Notes - This is the first record of H. comata from Venezuela and Goiás State (Brazil) (Fig. 4).

\section{Limnobatodinae Esaki}

\section{Limnobatodes paradoxus Hussey}

Known distribution - Honduras (Atlántida), Guyana (Upper Demerara-Berbice), French Guiana (?), Brazil (Amazonas), and Peru (?).

Material examined - 1 ㅇ $(\mathrm{NMNH})$ : 'Brazill: Pará:\Jacareacanga \June $\backslash$ F. Barbosa'.

Notes - This is the first record of L. paradoxus from Pará State (Brazil) (Fig. 5).

\section{VELIIDAE BRULLÉ}

\section{Microveliinae China and Usinger}

\section{Euvelia lata Polhemus and Polhemus}

Known distribution - Colombia (Putumayo) (Molano et al. 2016), Brazil (Amazonas, Pará, and Mato Grosso), and Peru (Loreto) (Fig. 6).

Material examined - 10 $\hat{\jmath}, 8$ ㅇ $(\mathrm{NMNH})$ : 'Brazil $\backslash$ R. Madeira 9-37\ Porto Velho $\backslash$ A. M. Olalla'.

Notes - This is the first record of E. lata from Rondônia State (Brazil).

\section{Euvelia mazzucconiae Aristizábal-García, Floriano, Moreira and Bispo}

Known distribution - Colombia (Antioquia) (Aristizábal-García et al. 2015).

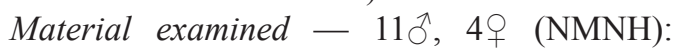
'Bolivia, S.A.\ R. Beni Puerto $\backslash$ Salinas 11-37 A. M. Olalla'. 19ð’, 27 ( $(\mathrm{NMNH})$ : 'Bolivia S. A.। Rio Beni\ Victoria 10-37 A. M. Olalla' 'Junction of Madre de Dios $\backslash$ and Beni Rivers'.

Notes - This is the first record of $E$. mazzucconiae from Bolivia (Fig. 7).

\section{Husseyella turmalis (Drake and Harris)}

Known distribution - United States (Florida) (Herring 1955), Mexico (?) (Smith and Polhemus 1978), Belize (Toledo) (Drake and Harris 1933), Jamaica (Trelawny) (Perez-Gelabert and Floriano 2016), Colombia (San Andrés y Providencia and Sucre) (Molano et al 2016), and Trinidad and Tobago (San Juan-Laventille and Río Claro-Mayaro) (Nieser and Alkins-Koo 1991).

Material examined - 11રิ, 7 우 (NMNH): 'Belize, Stann Creek $\backslash$ Twin Cays $\backslash$ West Pond, colln

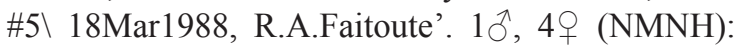
'Belize, Stann Creek $\backslash$ Dangriga (12km N) Salt Creek Lagoon\} 2 8 \text { Mar 1988\R. A. Faitoute, colln \#29'. }

Notes - This is the first record of H. turmalis from Stann Creek District (Belize) (Fig. 8).

\section{Veliinae Brullé}

\section{Oiovelia cunucunumana Drake and Maldonado-Capriles}

Known distribution - Colombia (Norte de Santander and Meta) (Molano et al. 2016), Venezuela (Distrito Federal and Amazonas), Brazil (Amapá, Amazonas, Pará, Bahia (Rodrigues and Moreira 2016), Minas Gerais, São Paulo, and Santa Catarina), Peru (Loreto), Paraguay (?), and Argentina (Corrientes).

Material examined - 10, 19 (NMNH): 'Parq. Nac. Cerro Cora $\backslash$ Depto. Amambay $\backslash$ Paraguay $\backslash 23$ II 1981' 'RD Cave $\backslash$ Colr' 'J. T. Polhemus $\backslash$ Collection 2014\ C.J. Drake Accession’.

Notes - Drake and Roze (1955) recorded $O$. cucucunumana from Paraguay River, Paraguay, without a specific locality. In this paper we confirm the occurrence of this species in Paraguay (Amambay Department) (Fig. 9).

\section{Paravelia conata (Hungerford)}

Known distribution - French Guiana (?) and Brazil (Amazonas, Pará, Mato Grosso, Goiás, and Espírito Santo).

Material examined - 10ิ, 2 ㅇ (NMNH): 'Trinidad, B. W. I. $\backslash$ Oct. $\backslash 27$ 29, 1938\Carl J. Drake' 'CJ Drake\Coll 1956'. 1ठð (NMNH): 'Venezuela, 
Amazonas $\backslash$ small stream $1 \mathrm{~km}$ camp $\backslash$ Alto Mavaca base camp $\backslash 2^{\circ} 1^{\prime} 30^{\prime \prime} \mathrm{N}, 65^{\circ} 7^{\prime} 0^{\prime \prime} \mathrm{W} \backslash 228 \mathrm{~m} .22^{\circ} \mathrm{C} 4$ Feb. $1989 \backslash$ CL 8006 D. A. Polhemus'. 1 ô (NMNH): 'Kartabo\ Bartica\ District \British Guiana 12 III-1924'. 10ิ (NMNH): 'Brazil: Rondonia\ Costa Marques $\backslash(15 \mathrm{kmw}) 12$ Nov1986 $\backslash$ B.A. Harrison'.

Notes - This is the first record of $P$. conata from Trinidad and Tobago, Venezuela, Guyana, and Rondônia State (Brazil) (Fig. 10).

\section{Platyvelia brachialis (Stål)}

Known distribution - United States (Pennsylvania, Ohio, District of Columbia, North Carolina, Arizona, Oklahoma, Texas, Georgia, Mississippi, Louisiana, and Florida), Mexico (Guerrero), Guatemala (Alta Verapaz), Nicaragua (?), Costa Rica (Limón), Panama (Panama), Cuba (Pinar del Río, Guantánamo), Jamaica (?), Haiti (Sud) (Perez-Gelabert and Floriano 2016), Dominican Republic (Monseñor Nouel (Perez-Gelabert and Floriano 2016) and San Cristóbal), Grenada (Saint George), Trinidad and Tobago (Tobago), Colombia (Norte de Santander) (Molano et al 2016), Brazil (Piauí, Pernambuco, Mato Grosso, Goiás, Mato Grosso do Sul, Minas Gerais, Espírito Santo, Rio de Janeiro, and Santa Catarina), Peru (Madre de Dios and Lima), and Argentina (Jujuy and Misiones).

Material examined $-2 \hat{0}, 7 \uparrow(\mathrm{NMNH})$ : 'Belize, Stann Creek $\backslash$ Placencia (2.5mi N), at $\backslash$ Rum Point. 5 Nov $1987 \backslash$ PJ Spangler \& RA Faitoute\ Placencia

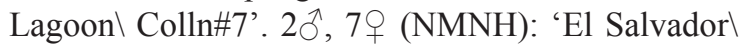
15Mi.Sw la Union \VII - 21- 1962\ Paul J- Spangler'. 1 으 (NMNH): 'Colombia\ Meta, $10 \mathrm{Km}$ S.I Villa Vicencio \III-3\&4-1969\ P. \& P. Spangler'. 10̄, 7 우 (NMNH): 'Venezuela, Amazonas $\backslash$ small blackwater trib. $\backslash$ to Rio Mavaca, $228 \mathrm{~m} . \backslash 2^{\circ} 1 \mathrm{~N}, 65^{\circ} 7 \mathrm{~W}$ pH $5.6 \backslash$ $23^{\circ} 11$ Feb $1989 \backslash$ CL 8005 D.A. Polhemus'.

Notes - This is the first record of P. brachialis from Belize, El Salvador, Meta Department (Colombia), and Venezuela (Fig. 11).

\section{Steinovelia virgata (White)}

Known distribution - Brazil (Amazonas, Pará, Mato Grosso, Mato Grosso do Sul, Minas Gerais, and Santa Catarina), Peru (Madre de Dios), Paraguay (?), and Argentina (Formosa, Corrientes, and Entre
Ríos).

Material examined - $1{ }^{\lambda}(\mathrm{NMNH})$ : 'Colombia: Meta\Puerto Lopez\} 9 \text { March 1971\S. S. Roback'. } 2 (NMNH): 'Bolivia: Depto Santa $\backslash$ Cruz, Prov San Esteban $\backslash$ Muyurina, 49KM N. $\backslash$ Santa Cruz, $112^{\circ}$ F T.'

Notes - This is the first record of S. virgata from Colombia and Bolivia (Fig. 12).

\section{GERRIDAE LEACH}

\section{Trepobatinae Matsuda}

\section{Halobatopsis platensis (Berg)}

Known distribution - Brazil (Piauí, Bahia, Mato Grosso, Goiás, Distrito Federal, Mato Grosso do Sul, Minas Gerais, Rio de Janeiro, São Paulo, Paraná, and Rio Grande do Sul), Argentina (Misiones, Corrientes, Santa Fe, Córdoba, Entre Ríos, and Buenos Aires), and Uruguay (Salto, Paysandu, Treinta y Tres, Florida, Lavalleja, Colonia, and Maldonado).

Material examined - 1 ( $(\mathrm{NMNH})$ : 'Brasil, Espirito Santo, Linhares Reserve, Rio $\backslash$ Barra Seca, 2 Feb 1998 30 $\backslash$ 04' 58S, 3952'57W, $\backslash$ M.E. Epstein, sta 24'. 10 ${ }^{\lambda}, 8$ ( 9 (NMNH): 'Rio Paucartambol Quiroz, Peru $1938 \backslash$ F. Woytkowski'.

Notes - This is the first record of H. platensis from Espírito Santo State (Brazil) and Peru (Fig. 13).

\section{Halobatopsis spiniventris Drake and Harris}

Known distribution - Brazil (São Paulo, Paraná, Santa Catarina, and Rio Grande do Sul) and Argentina (Misiones and Entre Ríos).

Material examined - $2 \hat{\jmath}$ (NMNH): 'Janeiro, Brazil October 1938\Carl J. Drake’. 1§, 1 우 (NMNH): 'Paraguay $\backslash$ Caaguazú District $\backslash$ Estancia Primeira $\backslash 1$ 4-XII 1931 \R F Hussey’.

Notes - This is the first record of $H$. spiniventris from Rio de Janeiro State (Brazil) and Paraguay (Fig. 14).

\section{Ovatametra obesa Kenaga}

Known distribution - Brazil (Amazonas, Pará, and Bahia).

Material examined $-89(\mathrm{NMNH}):$ 'Bolivia, Dept. Beni $\backslash$ Gral Jose Ballivian Prov. $\backslash$ savannah pond 
2 km. E. $\backslash$ of San Borja, 220 m. $\backslash 10$ Sept. 1989 CL $2502 \backslash$ D.A. \& J. T. Polhemus'.

Notes - This is the first record of O. obesa from Bolivia (Fig. 15).

\section{Gerrinae Leach}

\section{Limnogonus aduncus aduncus Drake and Harris}

Known distribution - Panama (Colón and Panama), Trinidad and Tobago (Tunapuna-Piarco and Siparia), Colombia (Magdalena, Córdoba, Antioquia, Chocó, Santander, Vichada (Padilla-Gil 2015), Risaralda, Valle Del Cauca, Quindío, Meta, Cauca, Caquetá, Nariño, Vaupés, Putumayo (PadillaGil 2015), and Amazonas), Venezuela (Aragua), Guyana (Demerara-Mahaica), Suriname (Wanica, Paramaribo, Sipawini, and Brokopondo), Brazil (Roraima, Amazonas, Pará, Pernambuco, Mato Grosso, Mato Grosso do Sul, Minas Gerais, Espírito Santo, Rio de Janeiro, São Paulo, Paraná, and Santa Catarina), Ecuador (?), Peru (Loreto, Amazonas, San Martín, Huánuco, Madre de Dios, Junín, and Ayacucho), Bolivia (Beni and Santa Cruz), Paraguay (?), and Argentina (Jujuy, Salta, Formosa, and Misiones).

Material Examined - 1 $\delta$ (NMNH): 'Brazil, Bahia, Canavieiras, $\backslash$ Rio Pardo, $28^{\circ} \backslash \mathrm{C}, 110 \mathrm{~m}, \backslash 7 \mathrm{Feb}$ 1998, $15^{\circ} 44^{\prime} \mathrm{S}, \backslash 38^{\circ} 58^{\prime}$ W, M.E. Epstein, sta $\backslash 31^{\prime}$.

Notes - This is the first record of L. a. aduncus from Bahia State (Brazil) (Fig. 16).

\section{Limnogonus recurvus Drake and Harris}

Known distribution - Brazil (Amazonas, Pará, Rondônia, Pernambuco, Mato Grosso, Minas Gerais, and São Paulo) and Bolivia (Beni and Santa Cruz).

Material Examined - $1 \hat{\jmath}(\mathrm{NMNH})$ : 'Brazil, Bahia, Canavieiras, $\backslash$ Rio Pardo, $28^{\circ} \backslash \mathrm{C}, 110 \mathrm{~m}, \backslash 7 \mathrm{Feb}$ 1998, $15^{\circ} 44^{\prime}$ S, $\backslash 38^{\circ} 58^{\prime}$ W, M.E. Epstein, sta $\backslash 31^{\prime}$.

Notes - This is the first record of L. recurvus from Bahia State (Brazil) (Fig. 17).

\section{ACKNOWLEDGMENTS}

We thank the National Museum of Natural History, Smithsonian Institution, Washington,
D.C. for providing research space and Thomas J. Henry (Systematic Entomology Laboratory, ARS, USDA, c/o NMNH) for support. CFBF thanks the State of São Paulo Research Foundation, FAPESP, for $\mathrm{PhD}$ (number 2013/16367-0) and international fellowships (BEPE, number 2015/09491-2). PCB thanks the National Council for Scientific and Technological Development, $\mathrm{CNPq}$, for a research fellowship (number 305275/2014-3). The Laboratory of Aquatic Biology from UNESP (Assis) is thankful for the financial support from FAPESP (number 12/21196-8).

\section{LITERATURE CITED}

Andersen NM (1982a) The Semiaquatic Bugs (Hemiptera, Gerromorpha). Phylogeny, adaptations, biogeography, and classification. Entomonograph 3: 1-455.

Andersen NM (1982b) Semiterrestrial water striders of the genera Eotrechus Kirkaldy and Chimarrhometra Bianchi (Insecta, Hemiptera, Gerridae). Steenstrupia 9(1): 1-25.

Andersen NM, Polhemus DA (2003) A new genus of terrestrial Mesoveliidae from the Seychelles (Hemiptera: Gerromorpha). Journal of the New York Entomological Society 111: 12-21.

Aristizábal-García H, Floriano CFB, Moreira, FFF, Bispo PC (2015) New species and notes on Microveliinae from northern South America (Hemiptera: Heteroptera: Veliidae). Zootaxa 3980(4): 591-596.

Damgaard J, Moreira FFF, Hayashi M, Weir TA, Zettel H (2012) Molecular phylogeny of the pond treaders (Insecta: Hemiptera: Heteroptera: Mesoveliidae), discussion of the fossil record and a checklist of species assigned to the family. Insect Systematics and Evolution 43: 175-212.

Drake CJ (1954) Synonymical data: descriptions of new Hydrometridae (Hemiptera). Great Basin Naturalist 14(3-4): 61-66.

Drake CJ, Harris HM (1933) New American Veliidae (Hemiptera). Proceedings of the Biological Society of Washington 46: 45-54.

Drake CJ, Roze JA (1955) A new species of Veloidea from Venezuela (Hemiptera: Veliidae). Bulletin of the Brooklyn Entomological Society 50: 106109. 
Molano F, Moreira FFF, Morales I (2016) New species and records of Microveliinae and Veliinae (Hemiptera: Heteroptera: Veliidae) from Colombia. Zootaxa 4171(3): 575-585.

MoreiraFFF(2015)The Semiaquatic Gerromorphans. pp 113-148. In, Panizzi A.R., Grazia (Eds) True Bugs (Heteroptera) of the Neotropics. Springer Science+Business Media, Dordrecht.

Moreira FFF (2016) Water Bugs Distributional Database. Available at: http://sites.google.com/ site/distributional database/. Accession date: 2016525.

Moreira FFF, Barbosa JF, Ribeiro JRI, Alecrim VP (2011) Checklist and distribution of semiaquatic and aquatic Heteroptera (Gerromorpha and Nepomorpha) occurring in Brazil. Zootaxa 2958: 1-74.

Moreira FFF, Rodrigues HDD, Barbosa JF, Reduciendo-Klementová B, Svitok M. (2016) New records of Gerromorpha and Nepomorpha (Insecta: Hemiptera: Heteroptera) from South America. Biodiversity Data Journal 4: 1-26.

Nieser N, Alkins-Koo, M (1991) The water bugs of Trinidad and Tobago. Occasional Paper 9, University of the West Indies, St. Augustine, Trinidad, iii $+127 \mathrm{pp}$.
Perez-Gelabert DE, Floriano CFB (2016) New Records of the Water Strider Platyvelia brachialis (Stal 1860) (Hemiptera: Heteroptera: Veliidae) from the Dominican Republic and Haiti, with a Checklist of the West Indian Veliidae. Proceedings of the Entomological Society of Washington 118(3)471-476.

Polhemus JT, Polhemus DA (2007) Global trends in the description of aquatic and semiaquatic Heteroptera species, 1758-2004. Tijdschrift voor Entomologie 150: 271-288.

Polhemus JT, Polhemus DA (2008) Global diversity of true bugs (Heteroptera; Insecta) in freshwater. Hydrobiologia 595: 379-391.

Spence JR, Andersen NM (1994) Biology of water striders: interactions between systematics and ecology. Annual Review of Entomology 39:101128.

Schuh RT, Slater JA (1995) True Bugs of the World (Hemiptera-Heteroptera). Cornell University Press, Ithaca, NY, xii + 336 pp.

Whittaker RJ, Araújo MB, Paul J, Ladle RJ, Watson JEM, Willis KJ (2005) Conservation biogeography: assessment and prospect. Diversity and Distributions 11: 3-23. 

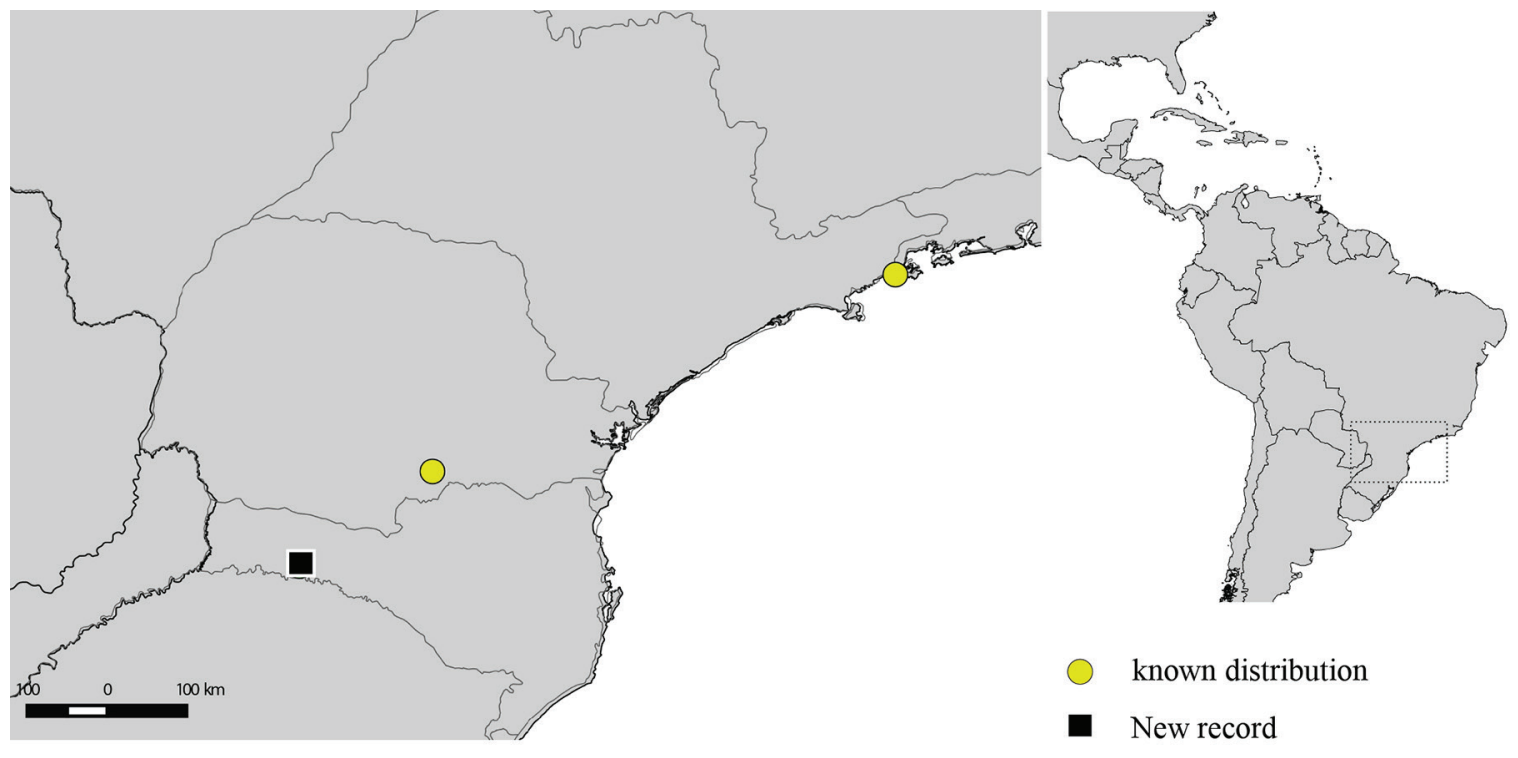

known distribution

- New record

Figure 1. Distribution map of Mesovelia bila in Brazil.
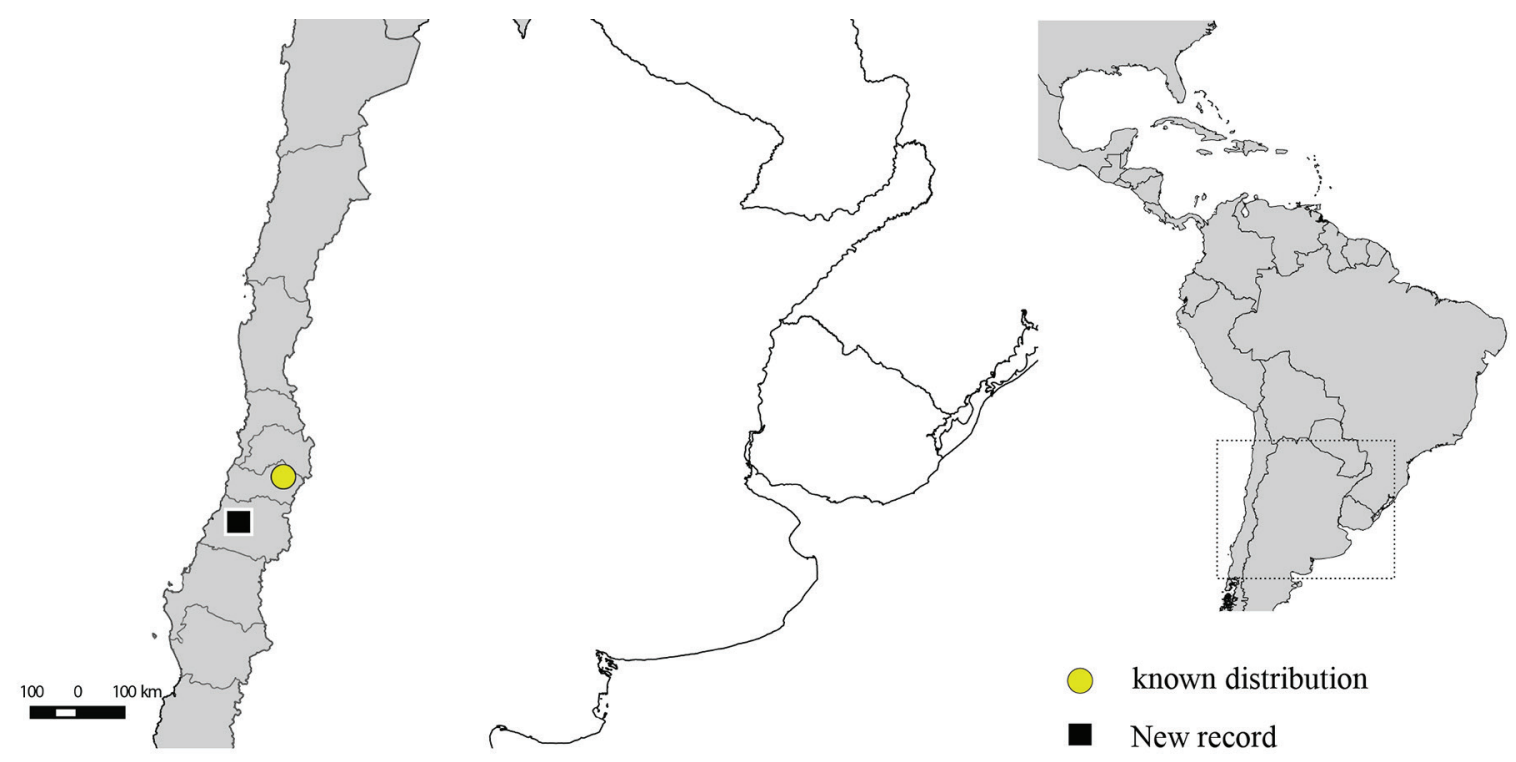

known distribution

- New record

Figure 2. Distribution map of Hydrometra argentina in Chile. 

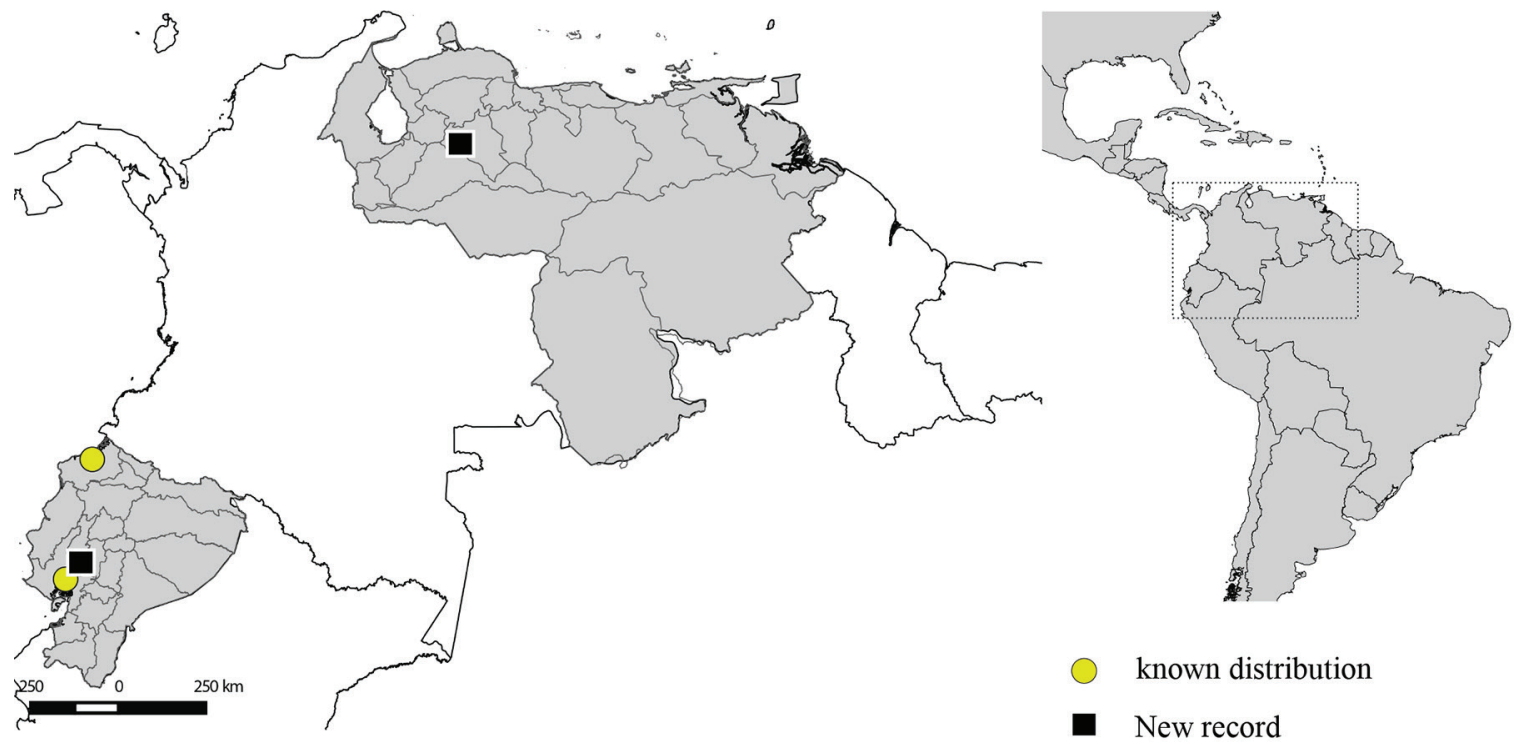

known distribution

- New record

Figure 3. Distribution map of Hydrometra caraiba in Venezuela and Ecuador.
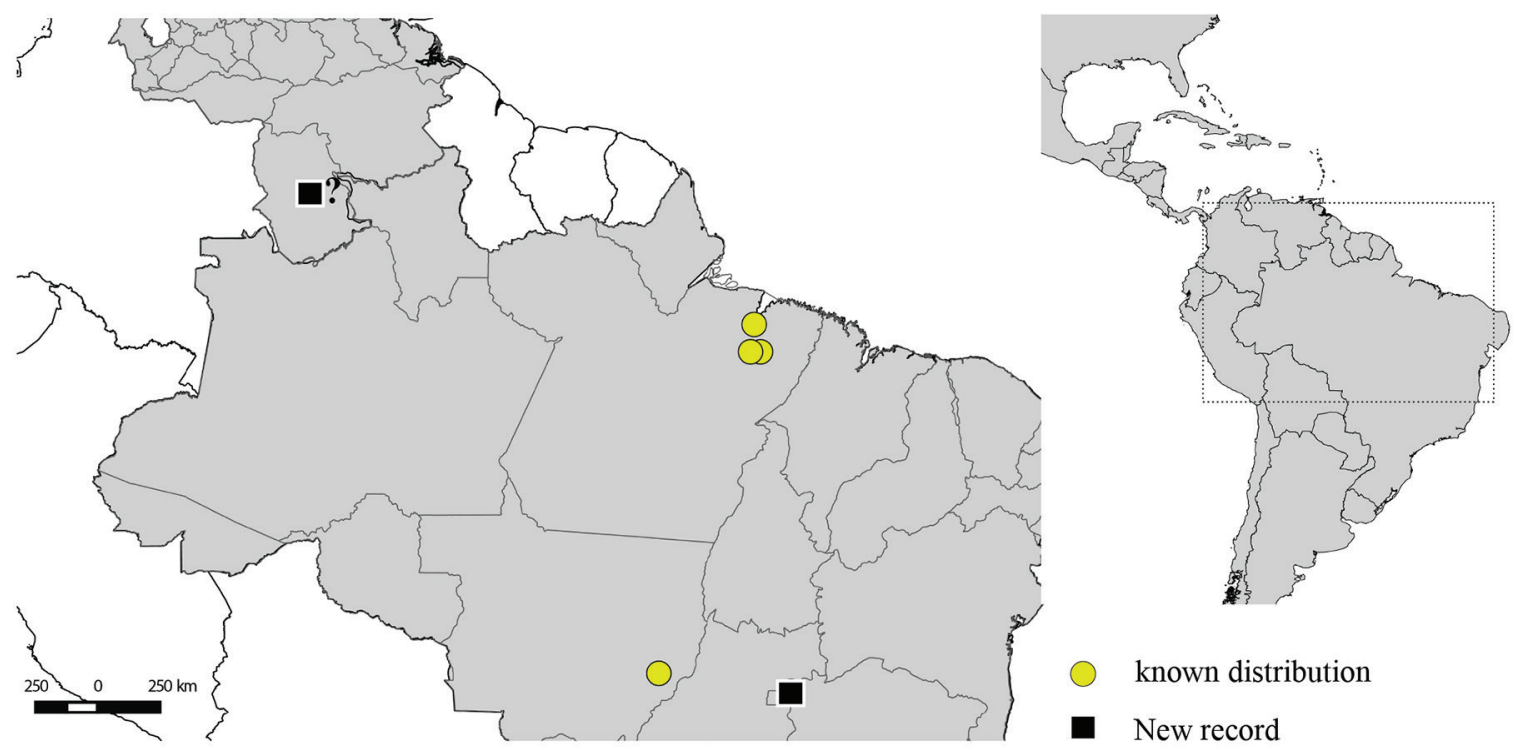

known distribution

- New record

Figure 4. Distribution map of Hydrometra comata in Venezuela and Brazil. 

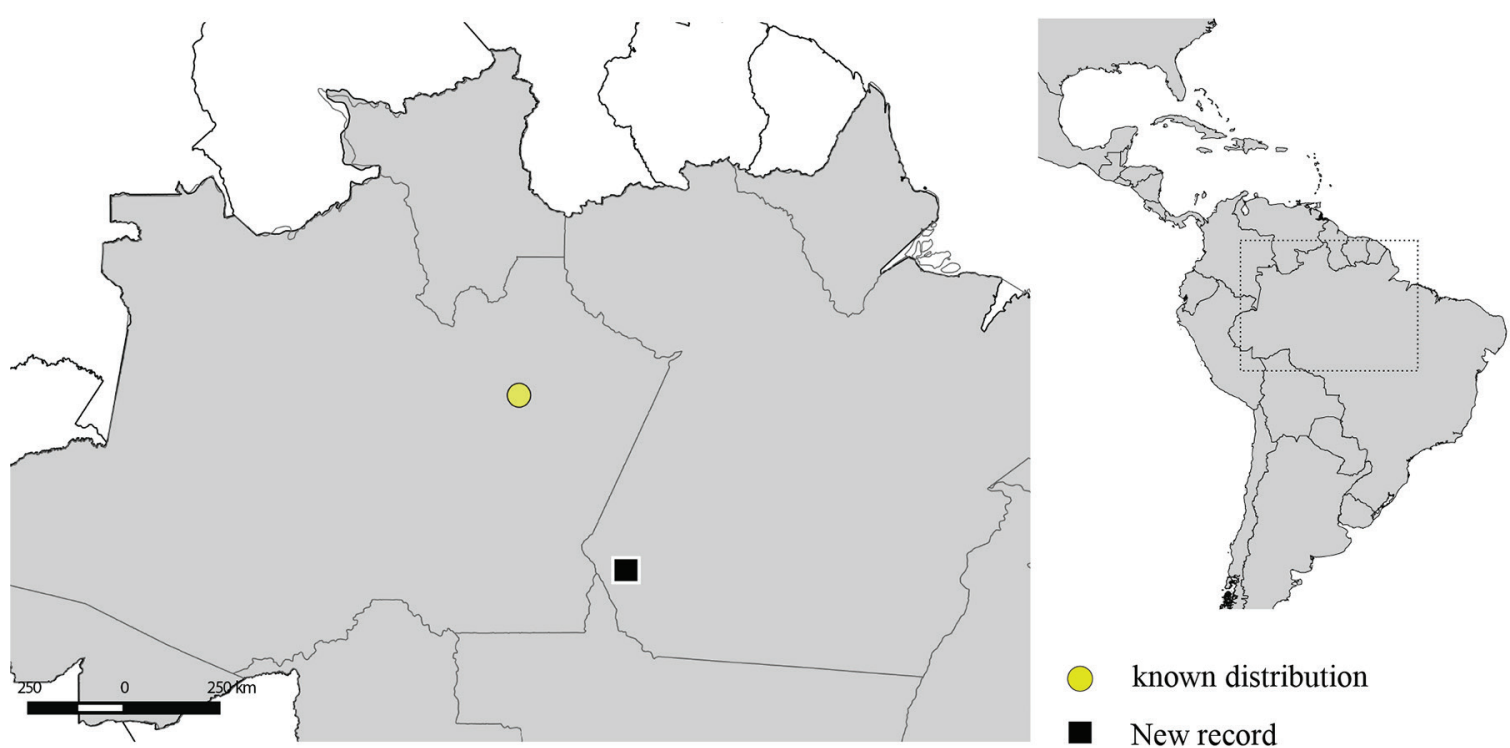

known distribution

New record

Figure 5. Distribution map of Limnobatodes paradoxus in Brazil.
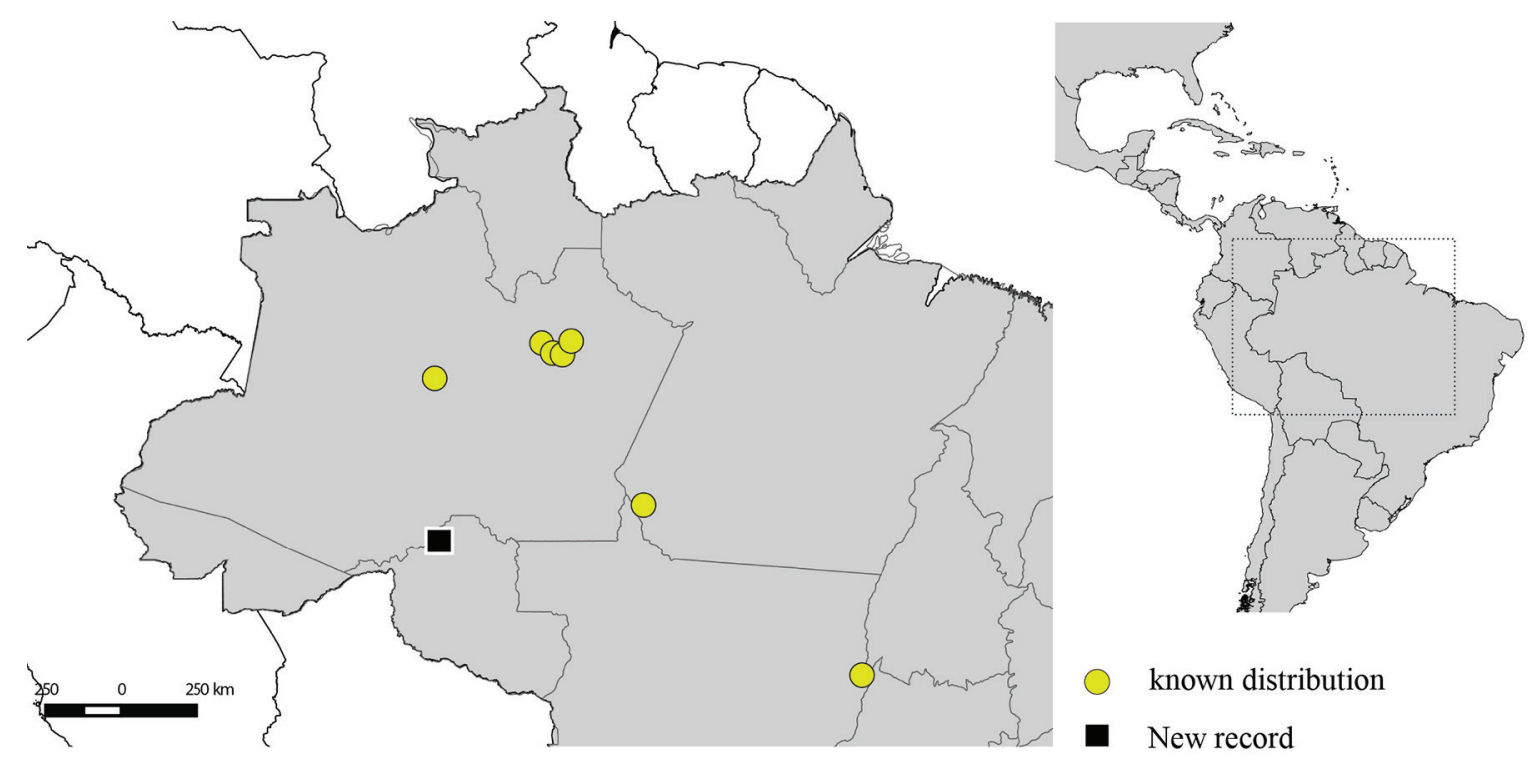

known distribution

New record

Figure 6. Distribution map of Euvelia lata in Brazil. 


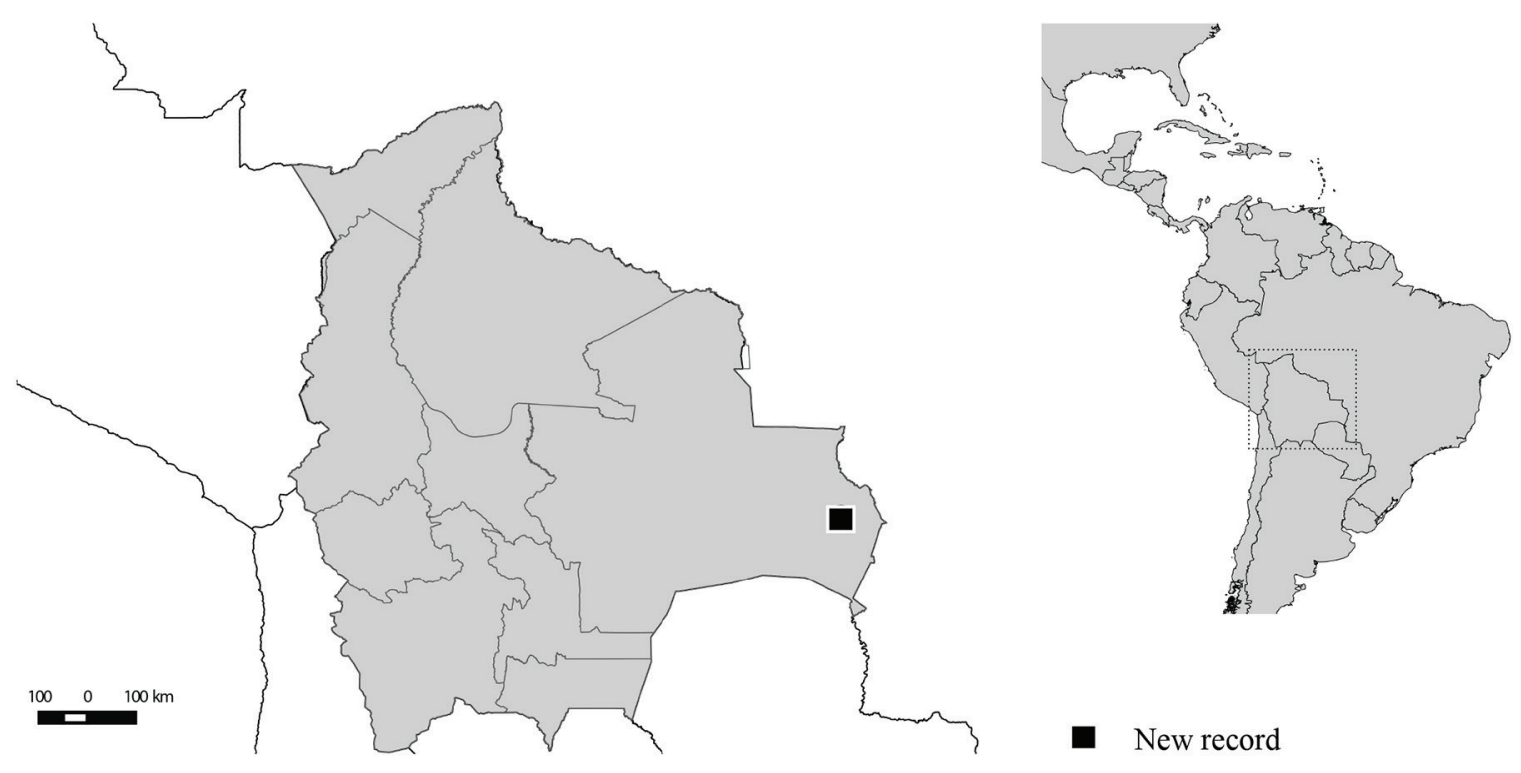

Figure 7. Distribution map of Euvelia mazzucconiae in Bolivia.

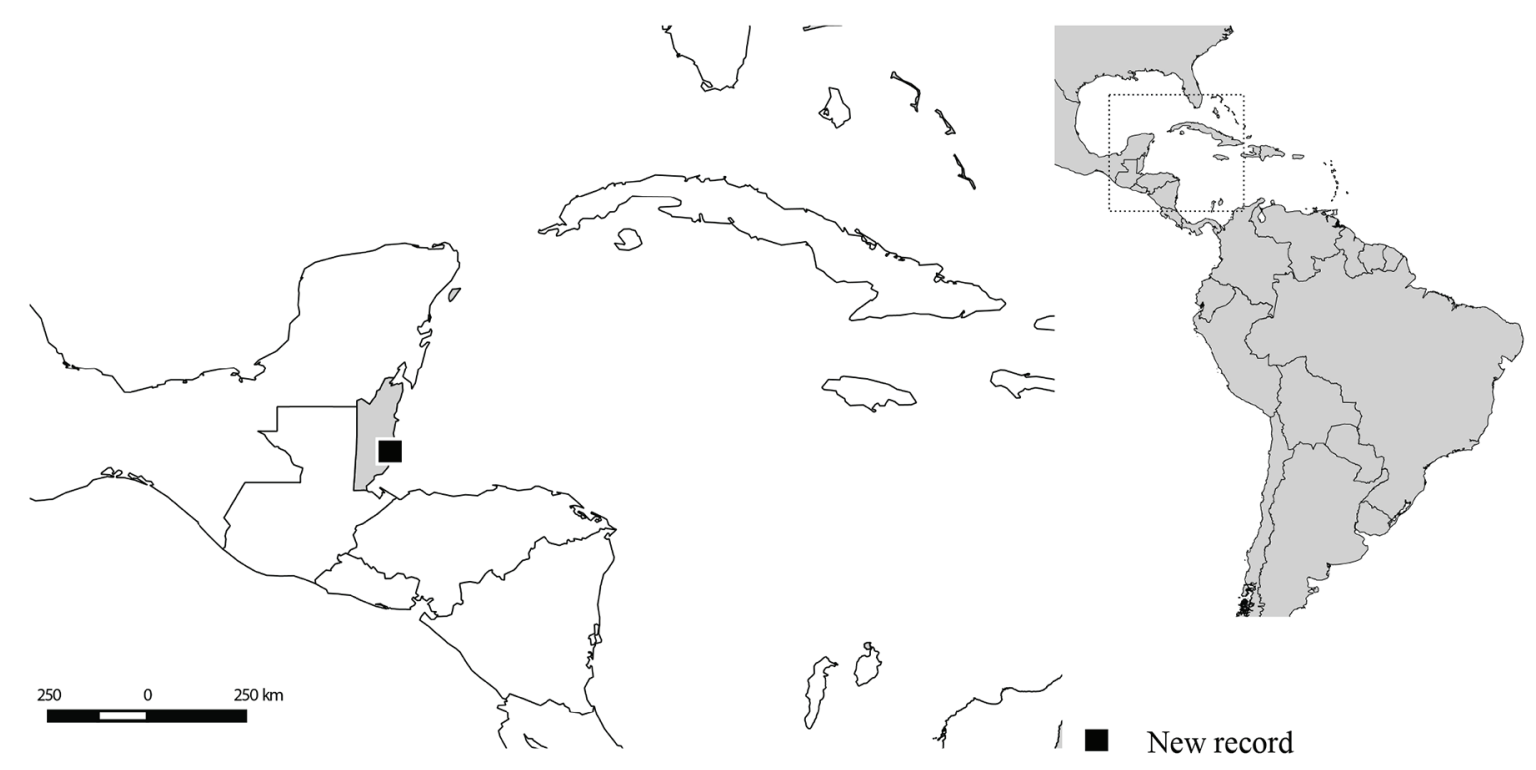

Figure 8. Distribution map of Husseyella turmalis in Belize. 

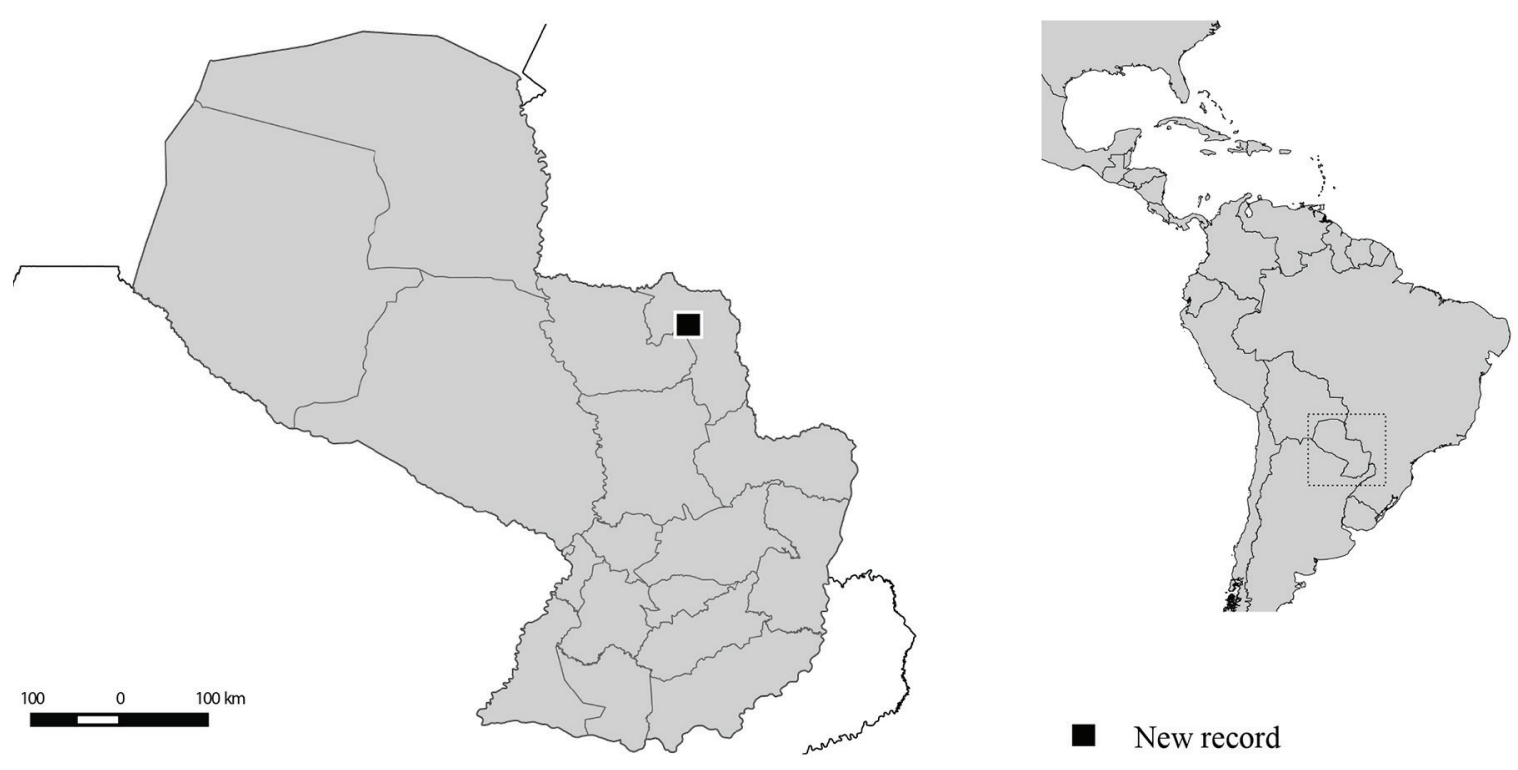

Figure 9. Distribution map of Oiovelia cunucunumana in Paraguay.
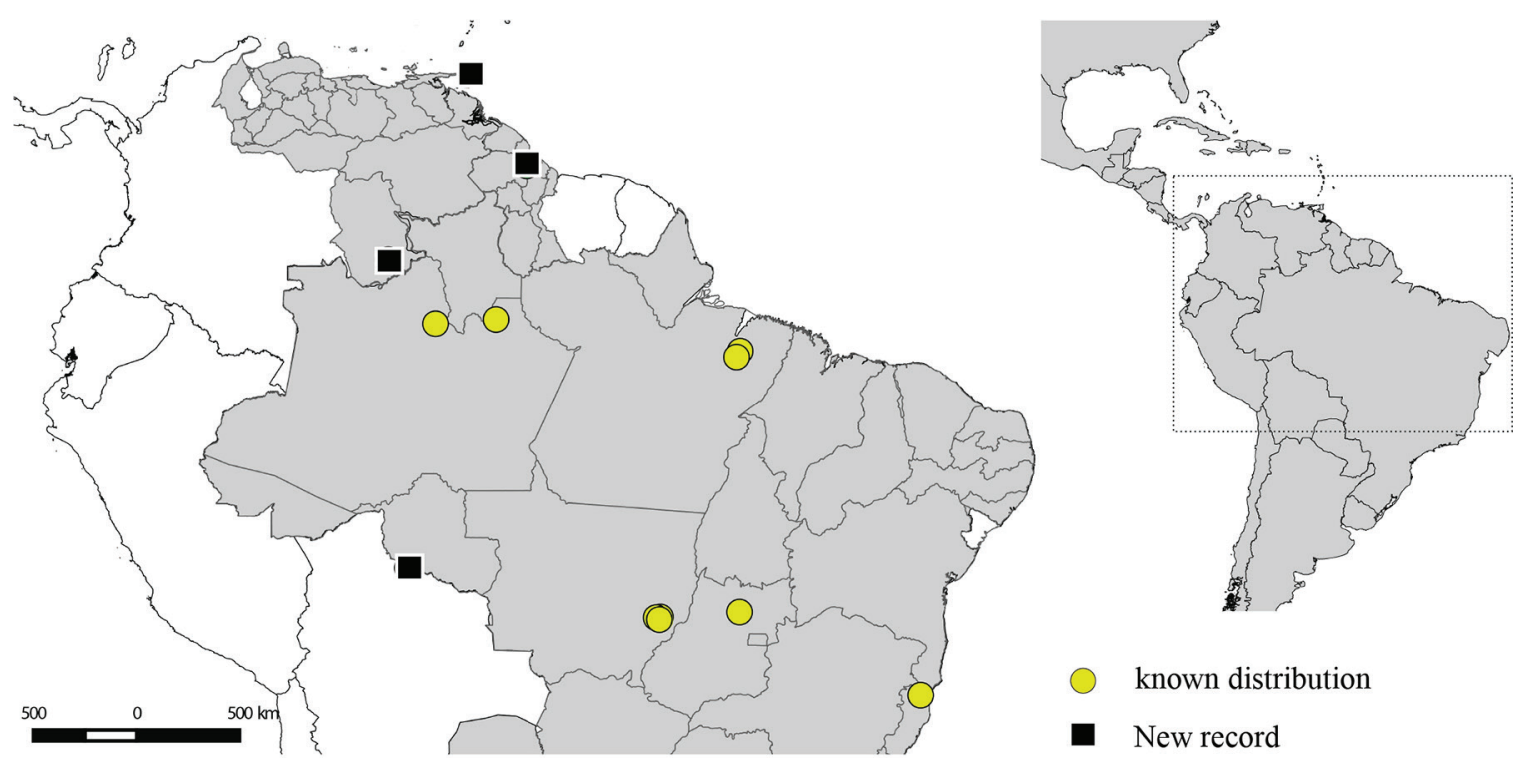

known distribution

- New record

Figure 10. Distribution map of Paravelia conata in Trinidad and Tobago, Guyana, Venezuela, and Brazil. 


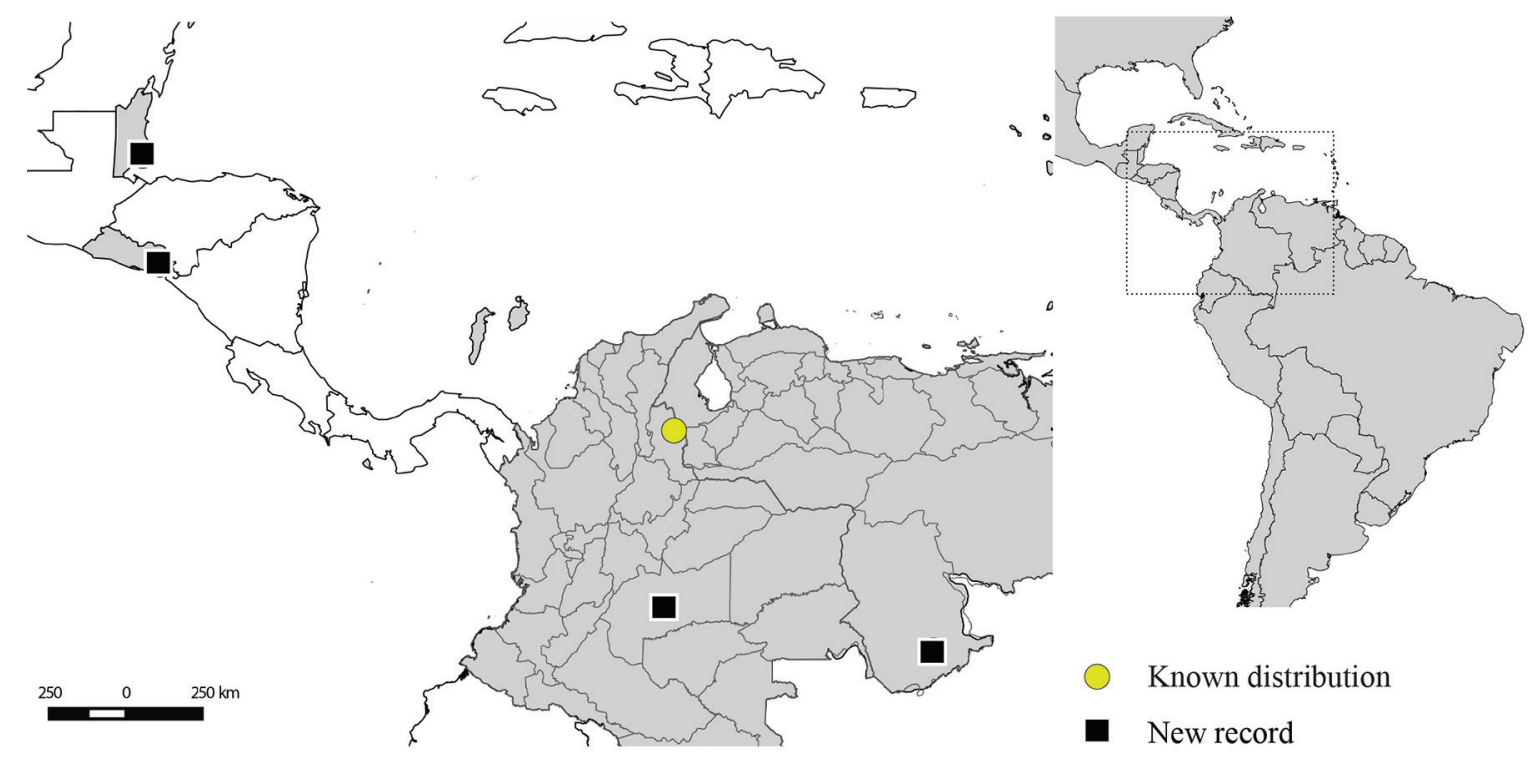

Figure 11. Distribution map of Platyvelia brachialis in Belize, El Salvador, Colombia, and Venezuela.

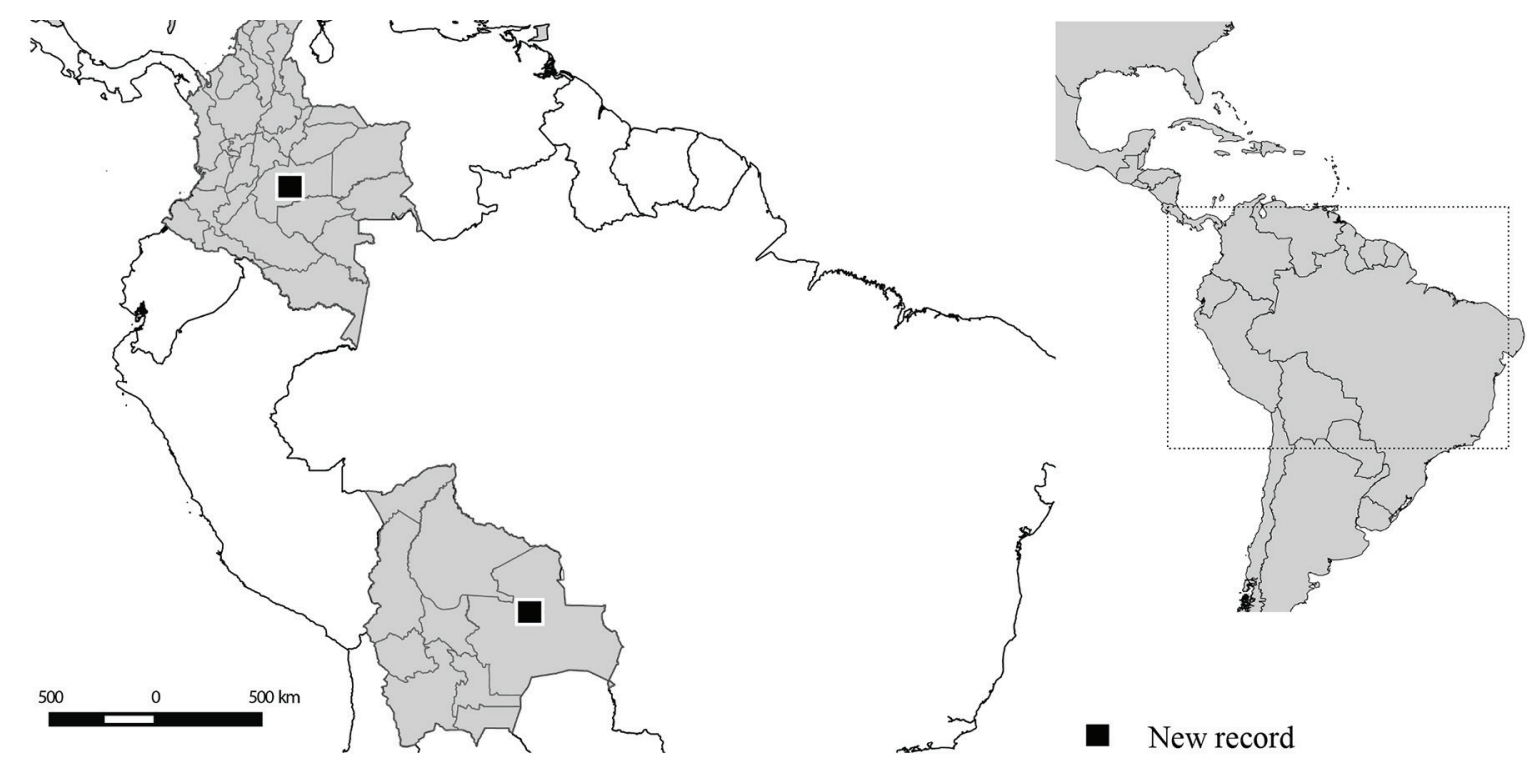

Figure 12. Distribution map of Steinovelia virgata in Colombia and Bolivia. 

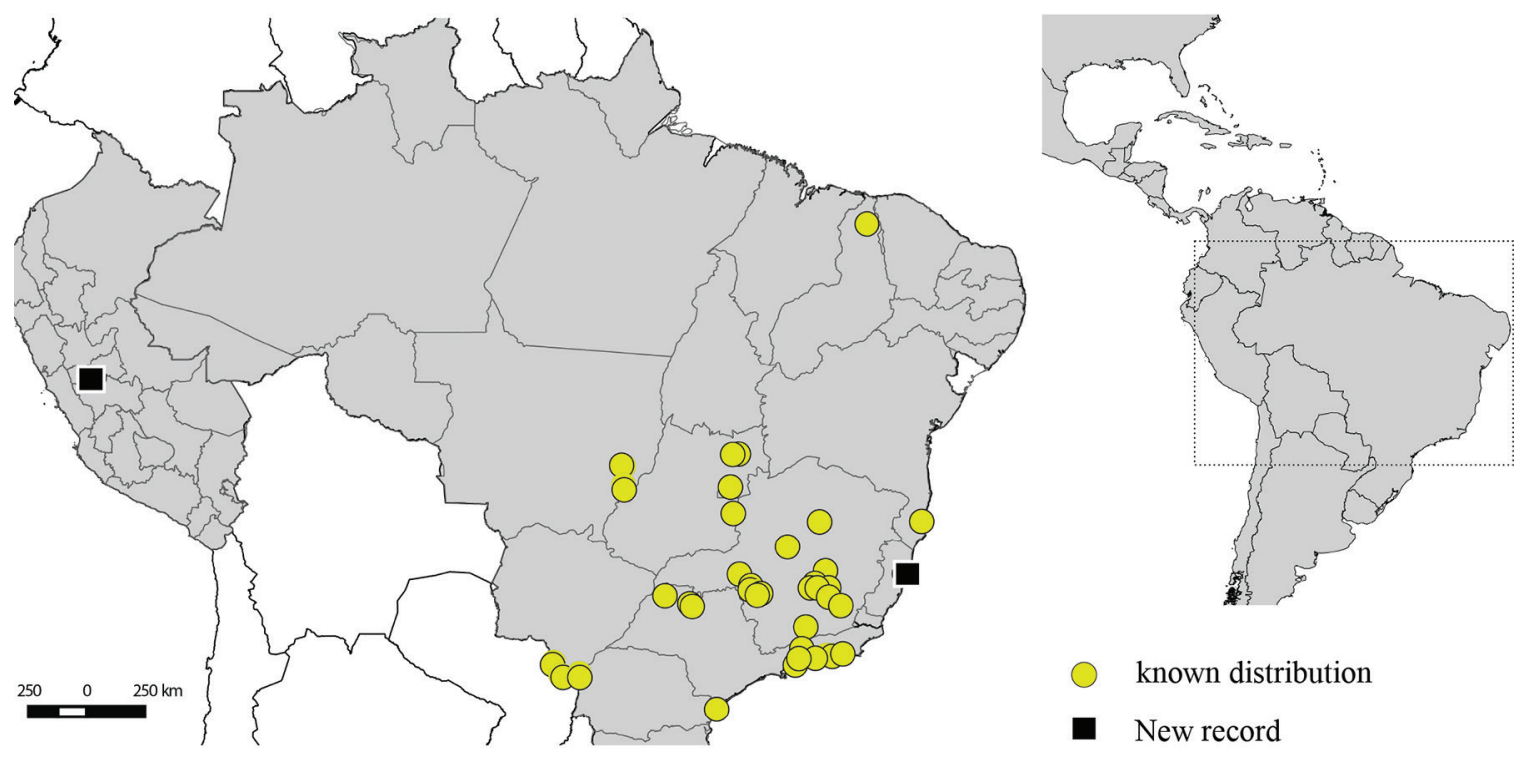

known distribution

- New record

Figure 13. Distribution map of Halobatopsis platensis in Brazil and Peru.
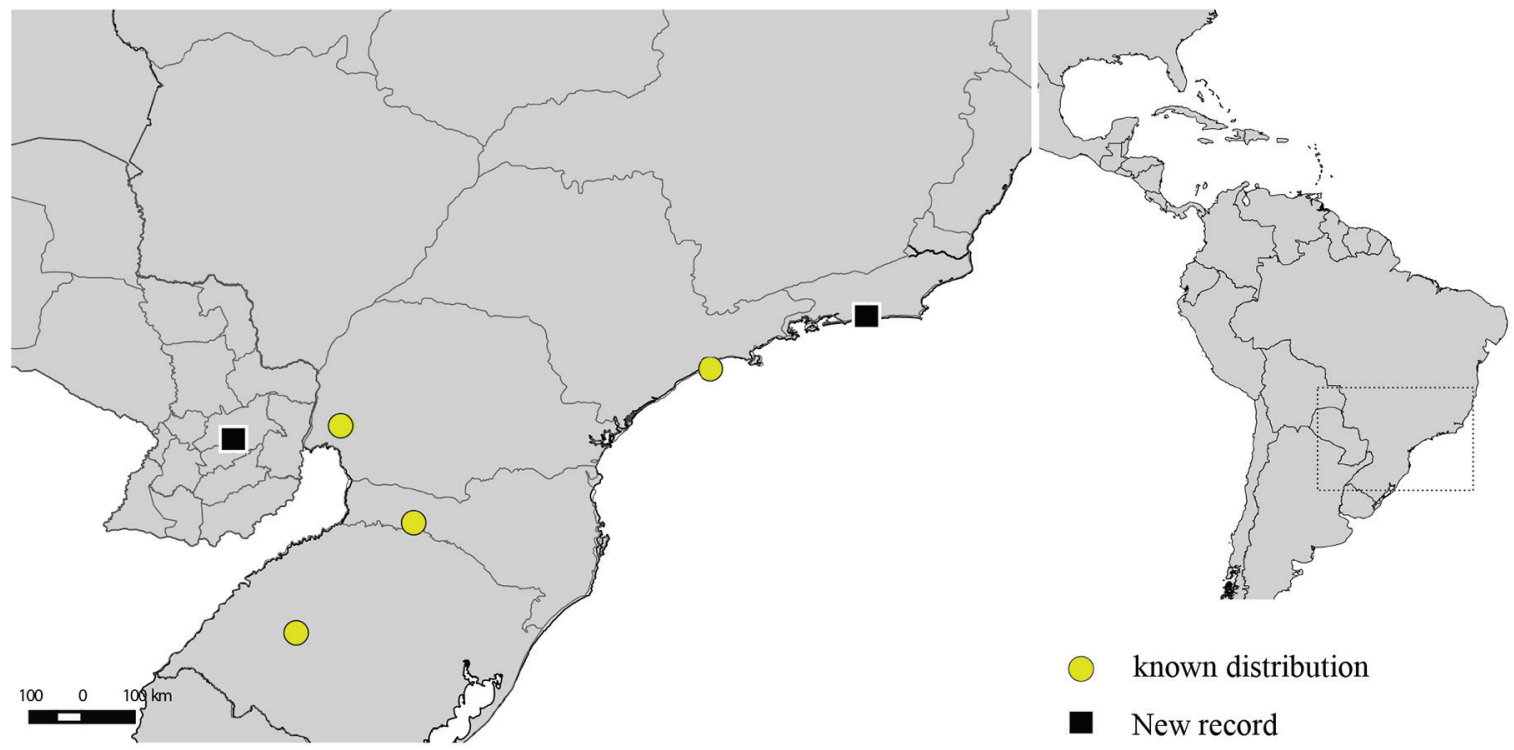

known distribution

- New record

Figure 14. Distribution map of Halobatopsis spiniventris in Brazil and Paraguay. 

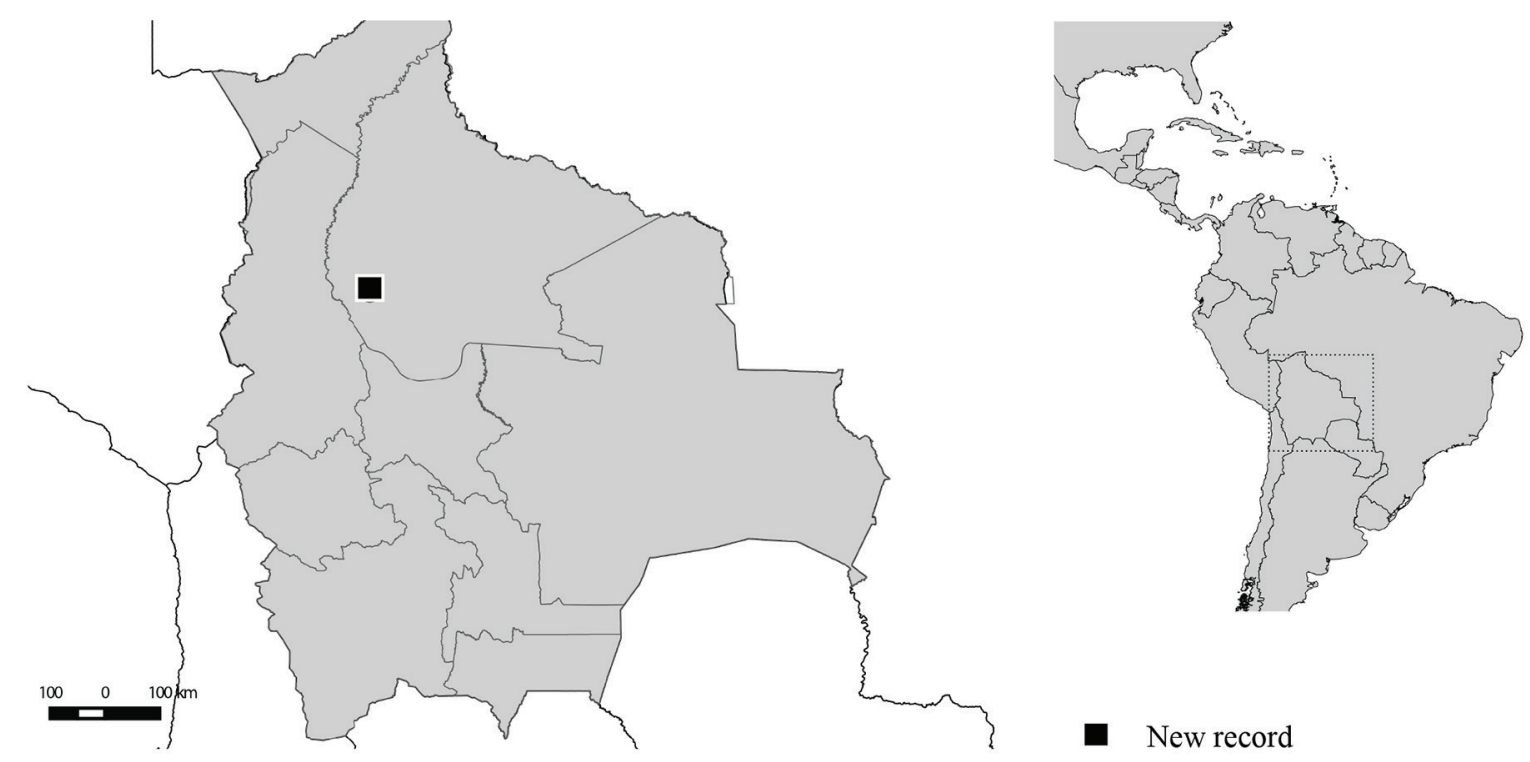

Figure 15. Distribution map of Ovatametra obesa in Bolivia.
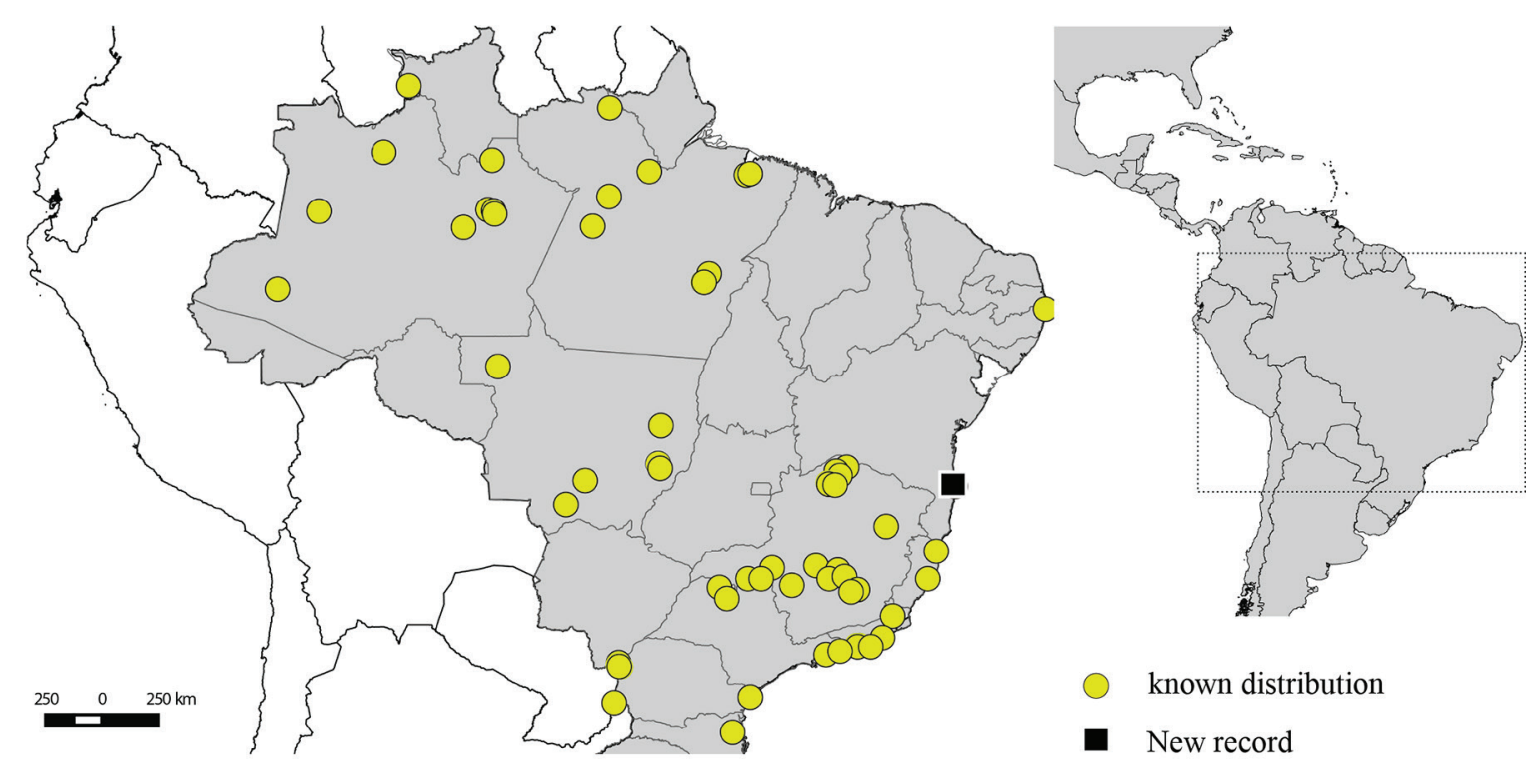

- known distribution

- New record

Figure 16. Distribution map of Limnogonus aduncus aduncus in Brazil. 

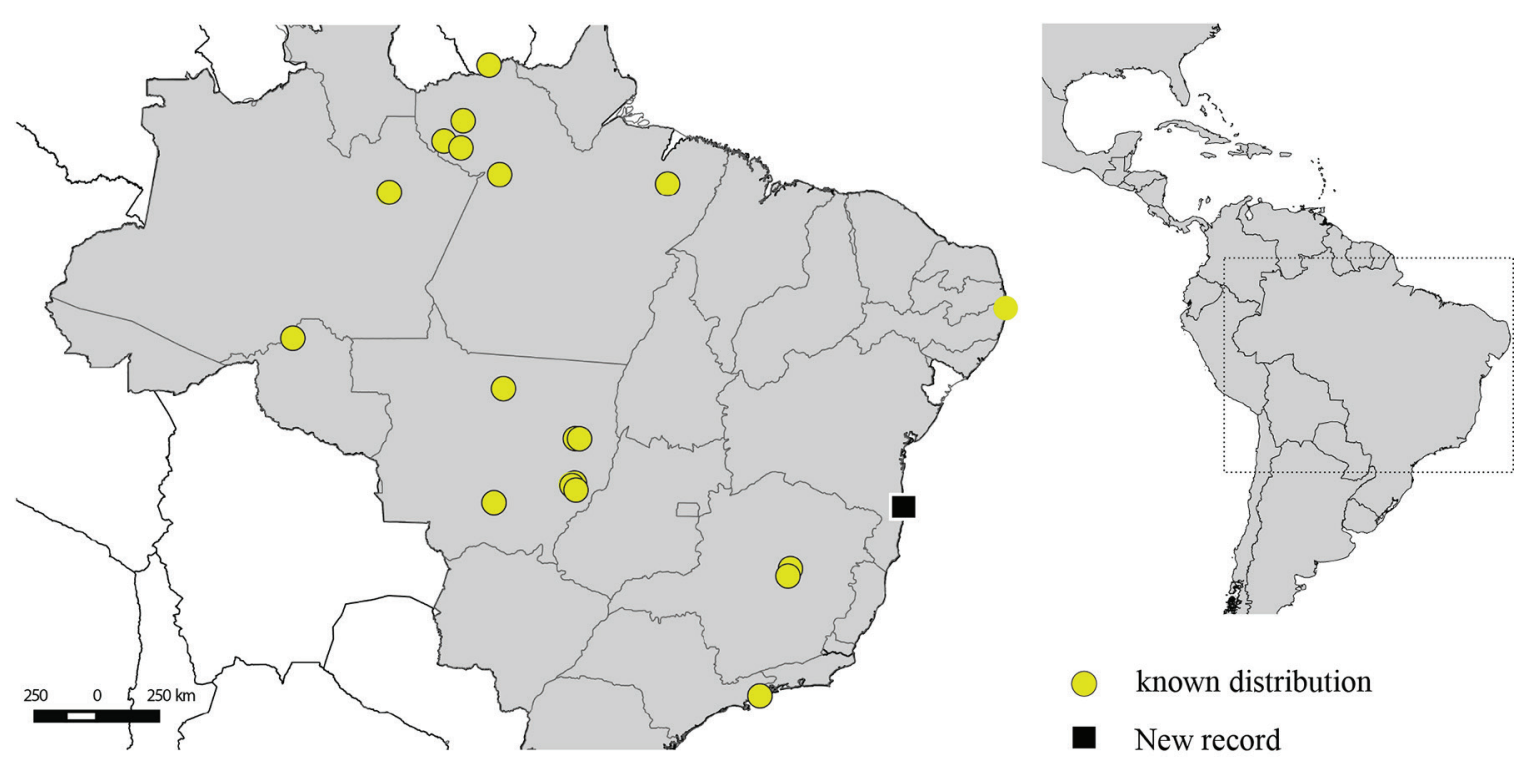

known distribution

Figure 17. Distribution map of Limnogonus r recurvus in Brazil. 